\title{
Community design: a collaborative approach for social integration
}

\section{Salomao David Cumbula}

Amalia Sabiescu

Lorenzo Cantoni
Università della Svizzera Italiana, Switzerland

Corresponding Author.

cumbulas@usi.ch

Università della Svizzera Italiana, Switzerland

asabiescu@usi.ch

Università della Svizzera Italiana, Switzerland cantoni@usi.ch

This paper describes a successful case of collaboration among a south-north project team, a Community Multimedia Centre (CMC), and community beneficiaries, for the design and implementation of a small-scale project to improve CMC services for the local community of Quelimane, in Mozambique. The project is part of RE-ACT, a broader scale research and development project which aimed to investigate the social meanings and understandings attributed by different stakeholders to Mozambican CMCs, and use these insights to co-design and implement CMC services with inherent relevance for the local communities. The case reported is considered the most successful of nine action research and co-design projects implemented through RE-ACT. The services designed for the Quelimane CMC can be considered a success not because of perfect alignment with initial goals but rather due to responsiveness and flexibility in the implementation approach: activities and goals were constantly revised by teams to cope with emerging challenges, while at the same time keeping a clear orientation towards set targets. The paper discusses

David, S., Sabiescu, A., Cantoni, L. (2017). Community design: a collaborative approach for social integration. The Journal of Community Informatics, 13(1), 177-192.

Date submitted: 2015-04-15. Date accepted: 2017-03-06.

Copyright (C), 2016 (the authors as stated). Licensed under the Creative Commons AttributionNonCommercial-ShareAlike 2.5. Available at: www.ci-journal.net/index.php/ciej/article/view/1209 
five underlying factors thought to heighten the chances of success of action research and co-design projects involving local communities, ranging from local proactivity and initiative, to commitment to project success, and high perceived self-efficacy of local stakeholders.

\section{Introduction}

The African continent is home of 33 of the 50 poorest countries in the world; the continent has $60 \%$ of the population living with less than 2 USD per day (Benatar, 2002). The world's developing nations live on the frontline of social instability, diseases, conflicts, corruption and climate change (Collins et al., 2009; Desjarlais, 1996). In the quest to find solutions to the problems faced by developing nations, approximately $800 \mathrm{bn}$ USD are invested yearly in Information and Communication Technologies for Development (ICT4D) by governments and donors (Heeks, 2010).

Since the early years of ICT4D, when Public Access Venues (PAVs) were the reference of the discipline, investment in ICT4D has been contested for two main reasons:

- investment and expenditure in ICT4D takes pathways to developing nations from developed countries (Heeks, 2008), where digital tools are produced;

- there is a lack of empirical evidence of ICT4D having a strong or even any record in creating substantial economic outcomes to solve the world's poor frontline problems (Patra et al., 2009).

PAVs were embraced as general ICT4D euphoria in the early 1990s, with more than one hundred donors funding PAV projects (Bailur, 2006). Telecentres were the first type of PAVs deployed in the developing context. However they failed to rise to their developmental potential, due to lack of relevant services for developing communities, insufficient staff training, and lack of programs by which people in the community could effectively expand their knowledge. One common problem was that the design of associated products and services did not take enough into account local practices. In fact, developing nations can be active members of today's knowledge societies; this, however, implies recognizing the importance of developing regions cultural heritage as a fundamental background of a community identity and patrimony (Morley et al., 2002; Vecco, 2010). In this view, ICT can provide added value to cultural heritage pedagogy, education and learning (Ott \& Pozzi, 2011; UNESCO Chair USI, 2016).

This paper seeks to present how shared perceptions on ICT4D can strengthen the relationship between different society spheres, empowering a social minority group to participate actively in community ICT4D design. The paper reports on the research and development project RE-ACT (Social REpresentations of Community Multimedia Centres in Mozambique and ACTions for Improvement). RE-ACT worked with Community Multimedia Centres (CMCs), the type of PAV most common in Mozambique, which combines a telecentre with a community radio. The project had a twofold aim: (i) to investigate the social meanings, perceptions, awareness, and understandings that different stakeholders attribute to CMCs in nine localities; and (ii) 
to design and implement services with inherent relevance for the concerned communities, aiming to improve the performance of the nine CMCs involved in the project.

This paper focuses on the second part of the project, the "improvement actions" designed for CMCs and surrounding communities, and in particular on the action implemented in the city of Quelimane. The improvement action conceived for the Quelimane CMC and surrounding community aimed at providing training in ICT for the underprivileged youth living in two nearby orphanages, and thus contributing to enhance their confidence, social recognition, and employability. This case is analysed looking at collaboration, social learning and sustainability as the most important factors underpinning its successful implementation.

\section{Community Multimedia Centres and RE-ACT improvement actions}

Mozambique is one of the world's least developed countries, with approximately 15 million inhabitants living in rural areas, out of 23 million people. The nation has a gross domestic product (GDP) of about 33 billion USD in 2015 (CIA, 2016). Mozambique has also embarked on pilot projects to deploy PAVs for rural development (UNDP, 1990) aiming to increase access to information and reduce the digital divide. The most common forms of PAVs deployed in Mozambique are telecentres, CMCs, cybercafés, Millennium villages, and libraries (Gaster, 2001; Macueve et al., 2009; Rega et al., 2011). The CMC is a PAV that combines telecentre facilities such as Internet, fax and phone services (Reilly \& Gomez, 2001) with a radio broadcasting in local languages managed mostly by locals (David et al., 2013).

RE-ACT "improvement actions" projects were small budget projects designed by CMCs' staff and local communities with the support of the RE-ACT team. Their purpose was to improve the social and (possibly) financial sustainability of CMCs. They were designed in an action research framework, and thus intended to support the design of CMC improved services, while enabling the local stakeholders to take full agency over their implementation. Project activities aimed also to create bridges that linked the $\mathrm{CMC}$ and the communities they served, lowering barriers for adoption of ICT services provided by the CMCs.

Improvement actions were conceived during a workshop held in Maputo at the University Eduardo Mondlane (February, 2014 ). The nine CMC directors, together with initiating agencies representatives, were invited to analyse the information gathered during the first phase of the RE-ACT project and to co-design possible improvement actions to be implemented with their CMC. The improvement actions selected by each CMC (Table 1) show a foremost concern with education, followed by the promotion of local economic welfare through revenue-making activities such as tourism. 
Table 1. Improvement actions for the nine CMCs involved in the RE-ACT project

\begin{tabular}{|c|l|l|l|}
\hline CMC & $\begin{array}{c}\text { Improvement action } \\
\text { Cuamba }\end{array}$ & $\begin{array}{c}\text { Beneficiarie } \\
\mathrm{s}\end{array}$ & \multicolumn{1}{|c|}{ Type } \\
\hline Chitima & $\begin{array}{c}\text { Communing } \\
\text { the Internet for } \\
\text { teachers and students }\end{array}$ & Students & Maintenance \\
\hline Chiure & Basic support training & Community & Maintenance \\
\hline Dondo & Creating a Cinema & Community & $\begin{array}{c}\text { Entertainme } \\
\text { nt }\end{array}$ \\
\hline $\begin{array}{c}\text { Ilha de } \\
\text { Moçambique }\end{array}$ & $\begin{array}{c}\text { Tourism platform for } \\
\text { the island }\end{array}$ & Community & Tourism \\
\hline Morrumbene & Local web platform & Community & Tourism \\
\hline $\begin{array}{c}\text { Quelimane } \\
\text { Sussudenga }\end{array}$ & Training in Informatics & Students & Education \\
\hline Xinavane & Training in Informatics & Students & Education \\
\hline
\end{tabular}

\section{Communities and cooperative design}

Over the last few decades, action research has been growing as both a research culture (Schuler, 2009) and a family of methodologies counter-acting notions of knowledge and power, to the extent of engaging communities in shaping the design of the research (Acker et al., 1991). Action-oriented research is usually associated with interpretative (Uttal, 2005) and critical theory inquiry paradigms (Guba \& Lincoln, 2005), requiring flexible study designs and a concern with producing practical, actionable knowledge that can inform practice and positive social change (Creswell, 2007). While action research has been labelled with different names, ranging from participatory action research, to co-design, up to action-oriented research (Argyris, 1996), the central tenet and driving factor underpinning this diversity is the concern with placing research in the service of the people (Reason \& Bradbury, 2005).

A common approach to differentiate action research from participatory research is to stress either the action taking or the participatory aspects in the research undertaken. Action research is mainly devoted to produce something and to sustain social change to the benefit of the stakeholders involved. The final aim is to come up with practical solutions to issues that concern people from different social groups or communities (Fine et al., 2000; Gaventa, 1993). At the same time, action research is equally a learning endeavour: it seeks to equip participants with skills in reflective thinking, decision-making, and action-taking (Adelman, 1993). Users' involvement in the design process allows ownership and contextualization of the technological solution, and decreases the risk of falling into design-reality gaps (Nhampossa, 2005; David et al., 2013). 
There is increasing evidence in the literature on the benefits of involving local stakeholders in design. The approach to co-design in ICT4D is shaped by the concerns of practitioners, researchers and international development organisations with raising public awareness and spreading ICT knowledge and skills to promote sustainable community development (Freeman, 1984; Kang, 2010). Co-design in this context implies at once that a project draws on a shared vision, fosters social learning, and promotes mutual understanding between the primary stakeholders, taking into account that those involved in the design process have somehow different perspectives and expectations, which should be adequately considered (Fien et al., 2007). Co-design is thought to result in higher quality of system requirements, higher system quality, and a better fit between the system and all intervenors (Steen at al., 2011).

\section{Case in focus: ICT training for the Quelimane underprivileged youth}

This section provides an in-depth view into one of the case studies in the RE-ACT project, involving the CMC in the city of Quelimane.

\section{The Quelimane CMC}

Quelimane is the fourth largest city of Mozambique, located in the Zambézia province. It has a population of approximately 225,000 inhabitants, $40 \%$ of whom are less than 15 years old (INE, 2012).

In the past two decades, several initiatives have been implemented for improving access to information and technology in Mozambique. One such initiative is Nova Radio Paz, a community radio founded by the Catholic Church in 1998. A community radio is a radio station that broadcasts in local languages, in this case in Portuguese and Chuabo, managed by local people and broadcasting to a limited area (usually not further than $100 \mathrm{~km}$ ). The radio is operated by the local Catholic cathedral and covers the entire municipality of Quelimane. Unlike commercial ones, this radio station does not run for profit. Its main competitor is Radio Moçambique (RM), the national radio broadcaster. In 2006, UNESCO, the Centre of Informatics of the University Eduardo Mondlane (CIUEM), and the Swiss Agency for Development and Cooperation (SDC), implemented an expansion project that consisted of adding to the existing Nova Radio Paz a telecentre overseen by the National Institute of Information and Communication Technologies (INTIC) (David et al., 2013). The Community Multimedia Centre (CMC) of Quelimane was born, as the aggregation of a telecentre and a community radio.

The Quelimane CMC is located on the 1st floor of the São Carlos Luanga primary school. Three classrooms are used as community radio, telecentre, and library. This CMC offers basic computer training (MS Word, Excel, and PowerPoint) in the telecentre, and courses of radio journalism and interview techniques within the community radio. The computer training course lasts for two months, two hours per day, Monday to Friday. The CMC also provides access to the Internet, fax, photocopies, typing services, printouts, and radio announcements (Rega et al., 2011). The CMC had five computers, four of which were allocated for computer training and one to the community radio. The $\mathrm{CMC}$ management is entrusted to a Catholic nun, who is 
supported by four local volunteers. These volunteers are young people who graduated from high school and are waiting for placement in the local university.

Frequent users of the $\mathrm{CMC}$ are office workers, students, teachers and business entrepreneurs. The CMC is not the only institution providing radio and ICT services in the city. The public and private sectors offer similar services, yet prices are much higher. These institutions have made larger investments and, due to their financial capacity, can provide competitive salaries. This often attracts the trained staff from the $\mathrm{CMC}$, who leave the community centre to work for these private institutions. The telecentre part of the $\mathrm{CMC}$ has difficulty to attract volunteers and staff. By contrast, the radio is successful in its attempt to attract radio staff, as its reputation is solid and widespread in the Centre and North of Quelimane. Nonetheless, volunteers of the radio do also leave for better positions: during the past two years, the radio has attracted volunteers from other provinces, who in few years come to be hired by public sector enterprises like Radio Moçambique (RM) and the Television of Moçambique (TVM).

Technical support for the telecentre part of the $\mathrm{CMC}$ is provided by the Centro de Apoio à informação e comunicação comunitaria (CAICC) (Rega et al., 2011). CAICC is a unit within the CIUEM that provides ideas for sharing information and resources between CMCs; it has a green line and postal line to either receive calls related to technical problems or fix damaged components of technological devices. As for the community radio part, support is provided by the Forúm Nacional das radios comunitárias (FORCOM), an organisation that acts as a lobbyist unit to promote and defend the interests of community radios (FORCOM community radio stations, n.d.).

\section{Key beneficiaries: The Quelimane underprivileged youth}

Like many others in the sub-Saharan region, the city of Quelimane faces social phenomena that range from having a very young population (INE, 2012), high fertility rates along with low child survival, AIDS epidemics (World Bank, 2007) and social exclusion phenomena. Orphans is a group most susceptible to social exclusion. With the support of the Diocese of Quelimane, the Institute of Social Security (INAS), and the Association Namuali, the city has been maintaining three orphanages: Casa Esperança, Aldeia da Paz, and Casa Familia.

The lack of orphanages forced the creation of seven houses that provide care to children in need. There are also houses that do not permanently host children. These new houses created a difference in the denomination, such that the people living in the orphanages are called "internals" and people living in the houses are called "externals". Internal orphans live in the orphanage and do not have a family, either because they have lost their parents, run away due to family abuses, or were abandoned. The external orphans have a house of their own but no elder person or relatives to care for them. Table 2 presents the number of residents in each orphanage, by age and gender. 
Table 2. Orphanages in Quelimane

\begin{tabular}{|l|l|l|l|l|l|}
\hline $\mathrm{Nr}$ & Orphanage & $\begin{array}{c}\text { Interna } \\
1\end{array}$ & External & Age & $\begin{array}{c}\text { Gende } \\
\mathrm{r}\end{array}$ \\
\hline 1 & $\begin{array}{c}\text { Casa } \\
\text { Esperança }\end{array}$ & 85 & 100 & $\begin{array}{c}7-1 \\
7\end{array}$ & Mixed \\
\hline 2 & Aldeia da Paz & 35 & 30 & $\begin{array}{c}7-1 \\
9\end{array}$ & $\begin{array}{c}\text { Femal } \\
\text { e }\end{array}$ \\
\hline 3 & Casa Familia & 60 & 100 & $\begin{array}{c}6-1 \\
8\end{array}$ & Male \\
\hline
\end{tabular}

The orphanages are dependent on welfare organizations, grants from government, donors, and fundraising activities. The orphanage management has also adopted innovative ways to provide care and expand relations between in-house residents and the outside world with a project known as Ataca, where anybody can be an educational tutor or a friend of a person leaving in the orphanage.

Attention to the inclusion of underprivileged youth has been on the agenda of governmental and non-governmental bodies in Mozambique. The Mozambican government has introduced reforms to primary education, notably the introduction of interdisciplinary, bilingual curricula, learner-centeredness and new teaching pedagogies (Guro \& Weber, 2010). The government is paying increasing attention to the impact of investment in education for development and poverty reduction by increasing earnings from employment and boosting the employability of the young labour force (Ez et al., 2012). The relationship between public education and economic development is far from well-defined, and global tendencies such as reduction of public spending on education and health programs can negatively impact on schooling for traditionally marginalized communities (Carnoy, 2000). Despite the fact that these marginalized social groups are the labour force for tomorrow, they face high social discrimination. Social discrimination originates from how society perceives them. Prior studies provided evidence that 10 to 17 -year-old boys or girls felt discriminated when their social situation became a reason for public debate that does not result in protection of their rights, when questioned about their living conditions, and when the lack of a paternal or maternal authority becomes a topic for derogatory conversations (Corcoran, 2002; Cornish \& Ghosh, 2007; Liepins, 2000; Sokoloff \& Dupont, 2005). Within this pattern, the special case of those underprivileged and young orphans stigmatized as HIV carriers stands out (Robson et al., 2006). Children from HIV positive mothers are often left under the care of their grandmother, cousins or aunts, who later stop caring for them under the excuse that they do not have the means to support them.

This stigma has corrosive effects on the Quelimane underprivileged youth, and generates an illness in the rest of society, leading to social differentials and lack of respect and compassion towards the underprivileged youth. For the underprivileged, stigmatization generates a viral load of hatred, a struggle that finds expression through minor vices taken from a tender age, known in many social contexts as "bad habits": drinking, smoking, and sexual misbehaviour. If not properly dealt with, these can 
escalate to self-inflicting, anti-social or deviating behaviours such as taking drugs, gambling, prostitution, and theft. These bad habits and vices are tightly connected to neglect and abuse, and to the desire for social recognition and acceptance (Burnham, 1993; Jones, 1993; Sacramone, 2006).

\section{Cooperative design of services for the Quelimane CMC}

The aim of the improvement action devised by the Quelimane CMC was to boost on a micro level socio-economic opportunities for the Quelimane orphans, through the provision of training in ICTs and radio services. ICT training sought to improve skills in computer usage (MS Word, Excel and PowerPoint, The Internet and social networks), while the radio course aimed at training people in radio journalism and production of radio programs. The actions were addressed primarily at the Quelimane orphans, for whom ICT training was intended as a tool for facilitating their social recognition and integration.

The core concept for the actions took shape in two moments: during the abovementioned workshop in Maputo with all involved CMCs' coordinators, and through a focus group in Quelimane with CMC staff, representatives of the social groups that would have benefitted from the actions, and representatives of the whole community. Two researchers in communication sciences specialized in ICT4D comprised the REACT team and were also present in both phases. The CMC staff included the CMC director, the telecentre responsible, two radio volunteers and the secretary. The three oldest boys and girls from Casa Esperança and Aldeia da Paz represented the underprivileged community beneficiating from the improvement action. Housewives, teachers, business entrepreneurs, and government employees, randomly selected among regular CMC users by CMC staff, represented the Quelimane community.

The Quelimane focus group session was held in the CMC where the improvement actions were to take place. To ensure that the underprivileged communities participated actively, the RE-ACT team had to understand the orphans' reality, get immersed in their daily activities, and understand their constraints when dealing with stigmatization.

To ensure that the workshop would produce useful results, the RE-ACT team provided to participants an overview of ICTs and the CMC's capabilities to deliver information through the use of technologies. Members of the Quelimane community understood the main role that ICTs play on their activities, with a special focus on mobile phones and computers. From the various interactions, it emerged that the community members see these devices as essential elements in their daily activities. The devices were used to alleviate stress by turning on the music, get informed by turning on the radio, and communicate with relatives through social networks and communication services like Facebook, Whatsapp, and Twitter.

The underprivileged youth merely related to the use of radio and showed curiosity about using mobile phones and computers to talk and make new friends using social networks like Facebook and Twitter. They also inquired about how the radio works on mobile devices and computers, as these features were not part of their reality. The knowledge 
about these technologies was everyday knowledge for most of the participants but not for the orphans. Members of the community and the CMC staff perceived that they had taken for granted that those technologies were part of general, background knowledge, shared by everybody. Therefore, the decision was made that the most relevant service to be provided to these youth was ICT training, inclusive of teaching on the potentialities of Internet and social networks.

The community representatives and the CMC staff had already entered the co-design process with an ideal perspective on what the improvement actions would be. The CMC staff had a predefined idea of the improvement actions: providing courses for ICT training (MS Word, Excel, PowerPoint). During the focus group, this initial idea was shaped and advanced with consideration of the needs of underprivileged youth, in order to increase their employability chances. In particular, the discussion focused on their need for social recognition and improved social status. One practical result of this discussion was an expansion in the training content to include teaching content on the use of Internet and social networking as well as three radio courses: radio journalism, production of radio programs, and multimedia techniques for radio. These courses would be offered to both groups of participants, the orphans and the rest of the young people, with the latter paying a course fee. Part of the technological infrastructure, course materials and the training expenses for the orphans were financed by RE-ACT.

The workshop discussions also tackled the issue of different learning capabilities, as people rarely learn in the same way but rather fashion learning around their pre-existing attitudes and abilities. One practical outcome of the discussion was the decision to provide a computer to each orphanage, to enable the orphans to practice during and after attending the courses. Community members probed the idea of allowing the underprivileged youth to express the knowledge acquired during training in a radio program to lower the risk of forgetting what they learned during the courses. They also insisted that the CMC had to be a venue where knowledge is applied to benefit both the privileged and the underprivileged. Co-design participants welcomed these ideas; the first idea implementation had to be accepted by the National Institute of Social Security (INAS), the entity that monitors that the activities do not interfere with the youths' ability to attend regular school, their mental and physical health, and that socially or morally the activities are not dangerous for the welfare of underprivileged youth.

For the project implementation, the RE-ACT team was assigned the task to prepare relevant educational material for the courses and to acquire the technological infrastructure - computers, recorders, Wi-Fi routers, internet providers, etc. Although Quelimane has experienced a significant increase in quality of life and income, the costs for computers, printers, and other ICTs related materials were much higher compared to Maputo, the capital city of Mozambique. Therefore, the RE-ACT team, based in Maputo, was in charge of sending the technical material to the CMC. A collaboration with CAICC was fundamental in this phase, as the centre provided access to their postal channel to exchange documents and technical materials with the CMCs.

Young people participating in the improvement actions were selected among boys and girls who had completed the 8th grade (year) of formal education. The 8th grade in the 
Mozambican education system corresponds to the first year of secondary education in the European system. An exception was made for the orphans, whose reading and writing skills could be equal to or higher than an 8th-grade student, even if they did not complete it. These skills were acknowledged with a school declaration. As shown in Table 3, it was decided that the total number of orphans participating in the improvement action was to be 33 for the entire duration of the project. 15 had to be girls and 18 boys, from Aldeia da Paz and Casa Familia respectively.

Table 3 Beneficiaries of the improvement action according to the initial plan.

\begin{tabular}{|c|c|c|c|c|}
\hline $\mathrm{Nr}$ & Orphanage & $\begin{array}{c}\text { Nr. } \\
\text { Orphans }\end{array}$ & $\begin{array}{c}\text { Age } \\
\text { group }\end{array}$ & $\begin{array}{c}\text { Gende } \\
\text { r }\end{array}$ \\
\hline 1 & $\begin{array}{c}\text { Aldeia da } \\
\text { Paz }\end{array}$ & 15 & $12-17$ & Girls \\
\hline 2 & Casa Familia & 18 & $13-17$ & Boys \\
\hline
\end{tabular}

\section{Implementation and results}

The ICT training was planned to spread over 18 months, from May 2012 to December 2013. The application was handled autonomously by the CMC, while the RE-ACT team provided remote assistance. During this time, the CMC staff drafted trimestral progress reports, sent through electronic email to the RE-ACT team. The first report was about the financial situation of the project, while the second related to the implementation of the project and its associated constraints.

The implementation of the action had to deviate in several ways from the initial plan, yet the challenges found were met by the local implementation team with on-the-spot solutions so that the project came to surpass the objectives it had set.

Initially, the $\mathrm{CMC}$ had concerns about the capacity to train the required number of underprivileged people requested by the RE-ACT team. Due to that concern, the CMC consulted the community and the RE-ACT team, and consequently decided to involve in the first batch only the youth from the two orphanages. The first group of people trained by the CMC were 14 youth from both the orphanages (six girls and eight boys). Their courses were held from June to October.

The second group of the course did not include girls as the person responsible for the girls orphanage considered that it was not an acceptable behaviour and example for the younger girls in the orphanage that older girls left the orphanage in the morning only to return at the end of the day. This was a major setback but a promise was made that during the summer holidays (November to January) girls would be allowed to attend the courses again. Later on, the orphanage administration decided that the girls would not be attending the course, due to an event that occurred in one orphanage. One of the girls who was to participate in the improvement actions became pregnant, an event which required the orphanage administration to enforce restrictive measures upon all the girls overseen by them. For the subsequent months, it was necessary to bring boys from external orphanages to "fill" the spaces left by the girls. 
The content of the courses also evolved in relation to the ideas brought in by the trainees. The first people trained by the improvement actions in the CMC presented an idea of a novel radio program to the CMC management and the RE-ACT team. This radio program was related to communication of childhood matters and later evolved to a more informative program about youth trends, famous personalities, music, and exchange of information about youth visions and challenges of coping with independent living as a young adult.

The program was aired by the community radio every day from 9:00 to 10:00 AM at the beginning. Once it became popular, the program started to be aired twice a week. The program started its first stage during November 2012. Its second phase started in December 2012 and stopped airing in February 2013. Most young people from the Quelimane city, students of the 8th to 10th grade, welcomed this program. The radio program was evaluated as highly successful by its listeners, based on an assessment obtained through the phone interactions held during the radio program.

This radio program proved to be a venue for obtaining a better job for its leading star, one of the underprivileged boys, who was invited by the Radio Moçambique of Quelimane to be part of their radio station, obtaining a fixed-term contract. This fact stimulated the rest of the group to work towards reaching the same or higher professional levels.

Overall, 79 students from both the orphans and the rest of the community were trained in the first year of the project, a number much higher than the initially planned number of trainees. Table 4 presents the distribution of people trained in ICTs and radio courses.

Table 4. Number of people trained in the Quelimane case

\begin{tabular}{|c|c|c|c|c|}
\hline Item & $\begin{array}{c}\text { Non- } \\
\text { orphans }\end{array}$ & \multicolumn{3}{|c|}{ Orphans } \\
\hline $\begin{array}{c}\text { ICT } \\
\text { Training } \\
\& \text { Radio } \\
\text { Course }\end{array}$ & 8 & Male & Female & Male \\
\hline $\begin{array}{c}\text { Only } \\
\text { Radio } \\
\text { Course }\end{array}$ & 6 & 13 & 6 & 20 \\
\hline Total & & 10 & 0 & 16 \\
\hline
\end{tabular}

\section{Discussion and conclusion}

This paper described a successful case of collaboration among an RE-ACT team, a $\mathrm{CMC}$, and community beneficiaries, for the design and implementation of a small budget project to improve CMC's services. The improvement action performed in the Quelimane CMC can be considered a success not because of its alignment with initial goals, but because of the manner in which activities and goals were constantly revised 
by the teams to cope with emerging challenges, while at the same time keeping a clear orientation towards set targets. The project succeeded in delivering training on ICTs and radio for both underprivileged and non-underprivileged youth in Quelimane. Yet, in many ways, the training deviated from the initial plan. For instance, the girls in the orphanages could not attend the courses due to restrictive measures set by the orphanage administration. Some significant and unexpected results were achieved, that in many ways exceeded the initially expected outcomes. Overall, the project trained more youth than initially planned. Also, one of the notable results was that the ICTs and radio training provided a foundation for the creation of a successful radio program that targets the youth community of Quelimane.

The case of the Quelimane CMC proved to be more successful than the other ones included in the project RE-ACT. The analysis of the underlying factors for the success of the co-designed improvement actions indicated that the most important ones revert around five aspects:

- commitment of the local implementation team;

- proactivity and local initiative;

- alignment between stakeholders' competences and tasks in the project;

- high perceived self-efficacy of local stakeholders;

- equalitarian relationship among stakeholders.

In this project, enabling the participation of all stakeholders from the design stage of the improvement action, and entrusting the local team with full power over implementation, helped to achieve intended goals. The accent fell, therefore, on the collaborative design of the actions, towards opening local agency for the implementation phase. This flexible approach to action research design is not novel. There have been similar approaches in which action research was customized for the needs of the context and the project goals, complemented with other methodologies or boosting the levels of local participation either towards the design or the implementation stages of the project development (e.g.: Ospina et al., 2004; Spinuzzi, 2005; Bowen, 2009).

First, the improvement action in this CMC was successful because the people managing the $\mathrm{CMC}$ were committed to the project and held high the cause of improving the life of the underprivileged youth. This commitment was especially evident for the CMC managing nun, who was in charge with overseeing the adequate implementation of the courses. The resource management was impeccable and attention was paid to keeping the staff working on the project motivated with resources acquired from the community course fees on a pro rata basis.

Second, the local stakeholders - both the CMC staff and the communities' representatives involved - were proactive in the implementation of the project, devising new approaches and steps to meet the encountered challenges. The project activities were always adapted to conditions, making the best of what was available or feasible. Actions not planned in the initial phase were also conceived. For instance, a computer 
was installed in the orphanages to allow youth to practice their newly acquired skills. This and other examples of local initiative reflect the demonstrated commitment of the local implementation team. Proactivity in the project implementation can be related to the fact that the local implementation team felt they owned the project; it was as much their project as it was one set up through a joint venture.

Third, such high level of proactivity was possible due to an adequate match between the stakeholders' expertise and assigned roles, tasks, and responsibilities in the project. The RE-ACT team gave advice on the best technological deals and oversaw the design of the courses. The project implementation was entirely managed by the local CMC staff, with inputs in relevant points from the beneficiaries and the RE-ACT team. The inclusion of individuals from the community skilled in project planning and management proved to be a line of support for the CMC management. This distributed expertise ensured an optimal investment of available resources.

ICT4D projects created in the early stages of ICT4D did not have a business plan that oversees the generation of sufficient resources like information, exchange of ideas and partnership to ensure continuous access to ICTs at an affordable cost. This aspect was not given sufficient attention in many community-based initiatives (Roman and Colle, 2002, 2003; Harris, 1999; Harris et al., 2003) and the Quelimane CMCs are not an exception. In the case of the Quelimane CMC action, having a skilled implementation team was also instrumental to efficient and wise management of the resources.

The effectiveness of this distributed expertise and the high level of local initiative can be related to a fourth aspect, the level of trust held by the local stakeholders in their capacity to carry over the project tasks to a satisfactory completion. This self-trust is well captured by Albert Bandura's (1998) concept of 'self-efficacy', referring to "beliefs in one's capabilities to organize and execute the courses of action required to produce given levels of attainment" (Bandura, 1998:52). Bandura also argues that people are more driven to action when they perceive that their action is likely to bring along the desired effects (Bandura, 1998). In this case, given that the stakeholders covered action areas aligned with their expertise, they were equally confident they could carry out the tasks well and motivated to invest the needed effort to bring them to completion.

Fifth, we draw attention to the relationship between stakeholders, which was characterized by equalitarian inputs in decision-making, inclusiveness and mutual trust. During the co-design phase, no member had the upper hand, rather inputs from all stakeholders were weighed and considered equally. Local stakeholders demonstrated critical thinking in their discussions and negotiations with the RE-ACT team. The local members of the staff would not act as to please the RE-ACT team members. For instance, while the RE-ACT team proposed a large number of trainees initially as a target, the CMC staff negotiated the number taking into account local human resources and infrastructural capacity. Also, the CMC management and the community representatives have understood the potential of international collaborations, and a trusting relationship was built during the entire process between the CMC and the REACT team. This proved to be vital for effective communication and joint work and for putting on the table problems and concerns as they were. This high level of trust did not 
lower the agency of the local implementation team by assigning a higher workload for the RE-ACT team. Rather, in many instances, the RE-ACT team acted as advisor for actions managed by the local team autonomously.

\section{References}

Adelman, C. (1993). "Kurt Lewin and the Origins of Action Research." Educational Action Research, 1: 1, 7-24.

Andela, V. B. (2006). Harnessing information and communication technologies to leverage scarce resources for cancer education, research and practice in developing countries. Health Research Policy and Systems, 4(1), 1.

Bandura A. (1998). Personal and collective efficacy in human adaptation and change. In Adair JG, Belanger D, Dion KL (Eds.), Advances in psychological science, Vol. 1: Personal, social and cultural aspects (p. 51-71). Hove, UK: Psychology Press.

Bowen, S. J. (2009). A critical artefact methodology: Using provocative conceptual designs to foster human-centred innovation. United Kingdom, Sheffield Hallam University Press.

Benatar, S. R. (2002). Reflections and recommendations on research ethics in developing countries. Social Science \& Medicine, 54(7), 1131-1141.

Bertot, J. C., Jaeger, P. T., \& Grimes, J. M. (2010). Using ICTs to create a culture of transparency: E-government and social media as openness and anti-corruption tools for societies. Government Information Quarterly, 27(3), 264-271.

Corcoran, M. (2002). Place attachment and community sentiment in marginalised neighbourhoods: a European case study. Canadian journal of urban research, 11(1), $47-68$.

Cornish, F., \& Ghosh, R. (2007). The necessary contradictions of "community-led" health promotion: a case study of HIV prevention in an Indian red light district. Social science \& Medicine, 64(2), 496-507.

Creech, H. (2006). Evaluation of UNESCO's Community Multimedia Centres. UNESCO. International Institute for Sustainable Development.

Creswell, J. W. (2007) Qualitative inquiry \& research design. Choosing among five approaches. Thousand Oaks: Sage.

Collins, D., Morduch, J., Rutherford, S., \& Ruthven, O. (2009). Portfolios of the poor: how the world's poor live on $\$ 2$ a day. USA, New Jersey, Princeton University Press.

Conger, S. (2015). Knowledge Management for Information and Communications Technologies for Development Programs in South Africa. Information Technology for Development, 21(1), 113-134.

David, S., Rega, I., Vannini, S., \& Cantoni, L. (2013). Co-designed improvement actions in Mozambique Community Multimedia Centres. In Proceedings: IFIP WG 9.4: Social Implications of Computers in Developing Countries, Ocho Ríos Jamaica, 19-22 May, 2013. Short Paper, pp. 1004-1017.

David, S., Sabiescu, A. G., \& Cantoni, L. (2013). Co-design with Communities. A Reflection on the Literature. J. Steyn \& A. G. Van der Vyver (Eds.). Proceedings of the 7th International Development Informatics Association (IDIA) Conference: Public and private access to ICTs in developing regions. Bangkok, Thailand, 1-3 Nov. 2013. 152-166. 
Desjarlais, R. (1996). World mental health: problems and priorities in low-income countries. England, Oxford, Oxford University Press.

FORCOM community radio stations. (n.d.). infoasaid.org. Retrieved October 16, 2013, from http://infoasaid.org/guide/Mozambique/organisation/forcom-community-radio-stations.

Gaster, P. (2001). A pilot telecentres project in Mozambique. Telecentres: Case Studies and Key Issues, 119. Mozambique, Maputo, Universidade Eduardo Mondlane.

Gomez, R. (2012). Libraries, telecentres, cybercafes and public access to ICT: International comparisons. Information Science Reference. Hershey, PA:IGI Global.

Guba, E. G., \& Lincoln, Y. S. (2005) Paradigmatic controversies, contradictions, and emerging confluences. In N. K. Denzin and Y. S. Lincoln (eds.) Handbook of Qualitative Research. 3rd ed. Thousand Oaks: Sage, 191-215.

Heeks, R. (2003). Most eGovernment-for-Development Projects Fail: How Can Risks be Reduced? (Working Paper No. 14). School of Environment and Development - The University of Manchester.

Macueve, G., Mandlate, J., Ginger, L., Gaster, P., \& Macome, E. (2009). Women's use of information and communication technologies in Mozambique: A tool for empowerment. African Women \& ICTs: Investigating Technology, Gender and Empowerment, 21-32.

Patra, R., Pal, J., \& Nedevschi, S. (2009). ICTD state of the union: Where have we reached and where are we headed. In Information and Communication Technologies and Development (ICTD), 2009 International Conference on (pp. 357-366). IEEE. April 17-19, Doha, Qatar.

Rega, I., Cantoni, L., Vannini, S., David, S., Baia, A., \& Macueve, G. (2011). Community Multimedia Centres in Mozambique: a Map. White Paper.

Kivunike, F. N., Ekenberg, L., Danielson, M., \& Tusubira, F. F. (2008). Rural communities in developing countries: An explorative review of the contribution of ICT on quality of life. In IADIS international conference ICT, society and human beings. April 9-12, 2008, Algarve, Portugal.

Liepins, R. (2000). New energies for an old idea: reworking approaches to community' in contemporary rural studies. Journal of rural studies, 16(1), 23-35.

Lucas, A. M., McManus, P., \& Thomas, G. (1986). Investigating learning from informal sources: Listening to conversations and observing play in science museums. European Journal of Science Education, 8(4), 341-352.

Nhampossa, J. L. (2005). Re-thinking technology transfer as technology translation: A case study of health information systems in Mozambique (Doctoral dissertation, University of Oslo, Norway).

Ospina, S., Dodge, J., Godsoe, B., Minieri, J., Reza, S., \& Schall, E. (2004). From Consent to Mutual Inquiry Balancing Democracy and Authority in Action Research. Action Research, 2(1), 47-69.

Oye, D., \& Malaysia, T. (2012). Inflation and Poverty in Nigeria: The Role of ICT in Poverty Reduction. Universal Journal of Management and Social Sciences, 2(7), 110-122.

Rega I. (2010). What do local people think about telecentres? A key issue for sustainability. $\mathrm{Ph}$. D. dissertation, Faculty of Communication Sciences, Università della Svizzera Italiana, Lugano, Switzerland. Available at: http://doc.rero.ch.

Reilly, K., \& Gomez, R. (2001). Comparing approaches: Telecentre evaluation experiences in Asia and Latin America. The Electronic Journal of Information Systems in Developing Countries, (4). 
Schuler, D. (2009). "Forward" to Hearn, G. N., Tacchi, J. A., Foth, M. and Foth, L., Action Research and New Media: Concepts, Methods, and Cases. Hampton Press, Cresskill, NJ.

Sokoloff, N. J., \& Dupont, I. (2005). Domestic violence at the intersections of race, class, and gender challenges and contributions to understanding violence against marginalized women in diverse communities. Violence against women, 11(1), 38-64.

Spinuzzi, C. (2005). The methodology of participatory design. Technical Communication, 52(2), 163-174.

Unwin, T. (Ed.). (2009). ICT4D: Information and Communication Technology for Development (1st ed.). Cambridge, UK: Cambridge University Press.

Wajcman, J. (2013). Managing like a man: Women and men in corporate management. John Wiley \& Sons. 